\title{
Explosion Box: A Learning Media of Ecosystem Components for Elementary School Student
}

\author{
Tsalats Zaidatul Nasriya ${ }^{1}$, Wuri Wuryandani ${ }^{2}$, Mulyono ${ }^{3}$ \\ ${ }^{1}$ Postgraduate School of Primary Education, Yogyakarta State University, Indonesia \\ ${ }^{2}$ Department of Primary Education, Yogyakarta State University, Indonesia \\ ${ }^{3}$ Tarbiyah Teaching Training Faculty, Malang State Islamic University, Indonesia \\ *Corresponding email: tsalatszaidatul.2019@student.uny.ac.id
}

Received: 13 August 2021

Accepted: 30 August 2021

Published: 30 August 2021

Abstract: Explosion Box as Learning Media of Ecosystem Components for Elementary School

Student. Objective: This research aims to describe the development of explosion box as learning media to deal with bored student in science learning to use textbooks. Method: Development of learning media in this study is implementing the Borg \& Gall. Field test were conducted on 5th grade elementary school students in Blitar, Indonesia. Finding: The results showed that the Explosion Box as learning media was valid category with a material expert validation: $93.3 \%$; design expert validation: $90 \%$; expert validation: $90 \%$. Results of trials: small group is $95.4 \%$ and large group is $94.4 \%$. Data pre-test and post-test results: before using product is 70.3 and after using product is 85.9 . Conclusion: Expert validation and student response questionnaires revealed that Explosion Box as learning media was very interesting and useful so that students do not get bored in the learning process.

Keywords: Explosion Box, elementary school student, learning media.

Abstrak: Explosion Box: Media Pembelajaran Komponen Ekosistem untuk Siswa Sekolah Dasar. Tujuan: Penelitian ini bertujuan untuk menjelaskan tentang pengembangan media pembelajaran Explosion Box untuk menjawab kebosanan siswa dalam belajar menggunakan textbooks. Metode: Metode yang digunakan pada penelitian ini mengacu pada jenis pengembangan menurut Borg \& Gall. Uji coba lapangan dilakukan pada siswa kelas 5 SD di Blitar, Indonesia. Temuan: Hasil menunjukkan bahwa media pembelajaran Explosion Box dinyatakan valid, dengan validasi ahli materi: 93,3\%, ahli desain: 90\%, ahli pembelajaran: 93,3\%. Hasil uji coba menunjukkan kelompok kecil: 95,4\% dan kelompok besar: 94,4\%. Data hasil pre-test dan post-test menunjukkan nilai ratarata sebelum menggunakan produk sebesar 70,3 dan setelah menggunakan produk sebesar 85,9. Kesimpulan: Validasi ahli dan respon siswa menyatakan bahwa media pembelajaran Explosion Box sangat menarik dan membantu siswa tidak bosan dalam proses pembelajaran.

Kata kunci: Explosion Box, siswa sekolah dasar, media pembelajaran.

To cite this article:

Nasriya, T, Z., Wuryandani, W., \& Mulyono. (2021). Explosion Box: A Learning Media of Ecosystem Components for Elementary School Student. Jurnal Pendidikan Progresif, 11(2), 338-348. doi: 10.23960/jpp.v11.i2.202115. 


\section{INTRODUCTION}

Curriculum development in Indonesia leads to a learning concept means "integrative science" based behaviorism learning theory, acquisition theory information and cognitive psychology theory (constructivism). Curriculum 2013 in science learning is a description of the goal and competencies that are expected to be achieved after an individual's learning activities. Science learning in elementary schools is the initial foundation in creating student who have scientific knowledge, skills and attitudes (Hidayah, Untari, \& Wardana, 2018). A teacher must be able to create appropriate learning conditions the characteristics of students and the character of the material which is delivered using supporting learning media. Science learning process is expected to be able improve the quality of education in Indonesia, this is based on the fact that the science learning process is still oriented on the results (result oriented), namely achievement the value of the National Examination. Science learning process hasn't touched on realm of the meaningfulness of that concept obtained at school (Irfan, Muhiddin, \& Ristiana, 2019).

In the science learning process in Indonesia, teachers focus on textbooks and carry out learning by providing direct experience to students in accordance with the 2013 curriculum. Science learning is difficult to learn just from textbooks, therefore to make it easier students studying science learning required a supporting tool calledthe learning media (Nata \& Putra, 2021). Teachers rarely use innovative learning media due to limited time and unfavorable conditions. The achievement of science learning outcomes in Indonesia is still classified as very low in comparison with other countries in the world, this can be seen from the data of The Organization for Co-operation and Development (OECD). From the results of the three times the survey (in year 2009, 2012, \& 2015) showed that the scores of Indonesian students are on science subject are still far away if compared to other countries (OECD, 2015). Furthermore, for the latest data in 2019, the average score of Indonesian students for science subject reached 389 with an OECD average score of 489 (Pengelola Web Kemdikbud, 2019). This is the causes that make students to become bored in the learning process so that the low learning result obtained by students (Farhana, Danang, \& Rosidi, 2020).

The low learning outcomes are caused by the selection of learning methods and media used by teachers in the learning process which are very inappropriate and management of learning activities that cannot increase student learning motivation optimally (Gumrowi, 2016). Media is a communication tool to make the teaching and learning process more effective (Mahbub, Kirana, \& Poedjiastoeti, 2016). Learning is a communication to convey an idea or the idea of teachers to students (Kuswanto, Yunarti, Lastri, Dapiokta, \& Adesti, 2021). Learning media are aids in conveying subject matter to students (Wulaningsih, Rusdi, \& Erawati, 2021). The use of media in the learning process is preferred because it facilitates the delivery of material from teacher to student (Ristanto et al., 2019). Stated that a function of using media is to provide the detail illustrations of objects which difficult to directly observe and help students to construct complicated concepts so it will be easy to understand for them (Miarsyah et al., 2020). Learning media is a means to convey information or a message to learners. The use of media in the learning process is expected to help teachers improve the learning outcomes of student. Learning objectives can be achieved by selecting and using appropriate learning media in learning activities.

The existence of learning media can support the learning process, facilitate students in understand the learning material, and improve the quality of teaching teachers who will have an impact on the quality of student learning outcomes 
(Paringan, 2018). The ability of teachers in creating and developing effective learning media and in accordance with the demands of technological development is still lacking(Apsari $\&$ Budiastuti, 2021). To overcome these problems, it is necessary to have appropriate learning media can support students in science learning. Therefore, in every teaching and learning activity the teacher should be able to provide and prepare learning media to help facilitate the teaching and learning process in order to achieve the expected learning objectives.

The learning media is important because they make students easier to understand the concepts (Ichsan, Sigit, \& Miarsyah, 2019). Students will be motivated to learn if the learning media used can make it easier to understand the material. Learning media is as a learning component that can enhance the interaction among the teacher, students and learning environments (Peppler \& Kafai, 2007). This was the basis for the need to the development of learning media containing science subject. This potential is to increase students' knowledge about ecosystem components. Therefore, the product being developed in this research is a form of visual media box called Explosion Box.

Explosion Box is commonly used as an alternative to the prize, birthday gift, graduation gifts, and others. There are several basic patterns in the making which consist of a rectangular shape pattern, a hexagon shape pattern, and an octagonal shape pattern. When the box is opened, you will see the arrangement of the parts of the box that are blooming, arranged so that it looks very beautiful and attractive, especially when decorated with components in the form of pictures, writing, decorations, small boxes, and others (Endah, 2016).

The Explosion Box as learning media in this study is a media box that contains a collection of materials and a summary of the material arranged to attract students' attention. The ability of this learning media is to strengthen the impression conveyed on a material so that a material can be easily remembered and learned. In addition, this media can also attract attention to increase student motivation (Niabatul, 2018). For this reason, this research aimed to develop a model and assessed the feasibility of Explosion Box as learning media for elementary school student in Science learning.

\section{METHODS}

This research implemented the Research and Development method using the Borg and Gall development model. According to Borg \& Gall model, this method has ten steps of research and development, are as follows: 1) research and collection preliminary, 2) research planning, 3) early product development, 4) expert validation, 5) product revision, 6) early test, 7) product revision, 8) field test, 9) final product revision, 10) dissemination. However, to simplify research and development, the researchers divided some procedures that became 6 main steps, namely: preliminary research and information collection, second step is planning, the development format of the preliminary product, field test and revision product, revision of the final product, dissemination.

Preliminary research and information collection is carried out to determine the needs in learning. The steps taken at this stage are literature studies and field studies. The literature study is carried out by collecting theories related to the development of Explosion Box as learning media of Ecosystem Components for elementary school student. In the field study step, the researcher carried out several stages of analysis, namely the analysis of textbooks and learning media that had been used, analysis of student needs and material analysis.

At the planning stage, the researcher analyzes the material to be compiled in the learning media, the steps taken include: analysis of the Competence Standard and Basic Competence, analysis of learning material, compiling the needs 
of students, developing indicators based on Competence Standard and Basic Competence. After the planning stage and developing format of the preliminary product, made the initial product design and then conducted field test and revision product filled by material, design and learning expert. Product trial aims to find out whether the product that made decent used or not and to what extent the product is made can reach target (Arifin, 2011). This research was conducted in 5th grade elementary school student, namely MI Perwanida Blitar. The last stage was conducted final revised and dissemination.

The type of data in this research is qualitative and quantitative data. Qualitative data obtain from criticism, comments and suggestions of the experts, while quantitative data is a point the assessment by the experts. The instruments used in the collection of data are questionnaire, interview and observation. Collecting data test is pre-test and post-test for the students to know the comparative effectiveness of learning between before and after using the learning media Explosion Box. The question of pre-test and posttest consists of 10 multiple choice question.

After obtained questionnaire data, then do analysis to obtain answers about data validated. By using the standard category: (1) 0\% - 25.99\% is "Not Valid" with full revision, (2) $26 \%$ $50.99 \%$ is "Less Valid" with revision of some,
(3) $51 \%-75.99 \%$ is "Valid Enough" with little revision, (4) $76 \%-100 \%$ is "Valid" without revision. In this study, the minimum feasibility value was determined to be "Valid". Thus, if material experts, media experts and learning experts provide "Valid" final results, then the product developed is suitable for use in learning activities.

The test results used to analyze the effectiveness the product, is about test results (pre-test and post-test) of the material components of ecosystem at the time before and after using the product learning media Explosion Box. The researchers calculated the average results of pre-test and post-test then calculated the difference.

\section{- RESULT AND DISCUSSIONS}

In learning, the use of media becomes a very important part and is generally used as a learning tool (Kasim, Haryanto, \& Katili, 2021). The media developed in this study is a learning media in the form of an Explosion Box to support the learning of Ecosystem Components at the SD/ MI level. The Explosion Box based as a means to help facilitate the learning process for 5 th grade students. Moreover, this learning media can also be used as a means of attracting student learning motivation and helping students understand the material with current and fun media. The following is a presentation of developing the Explosion Box as learning media of Ecosystem Components.

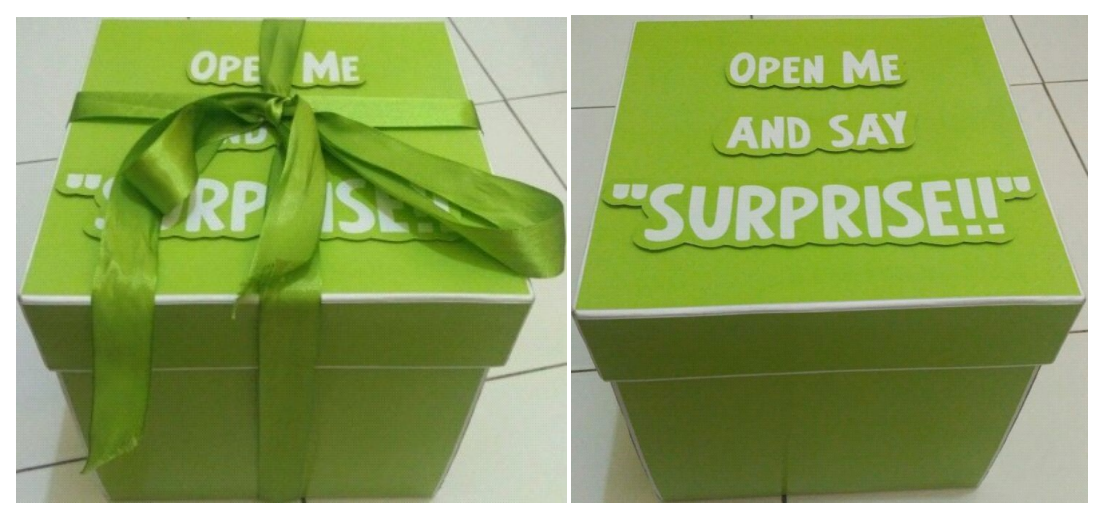

Figure 1. Display the learning media explosion box 
On the outside (close box) there is the text "Open me and say Surprise". The meaning of the text is as supporting the concept of a media Explosion Box that is a box of surprises. One of the characteristics of student creativity is being able to imagine (Botty \& Handoyo, 2018). By reading the sentences, students will imagine opening the box as a gift (surprise), so that it can increase student creativity. The text using the font style: Comic Sans MS with the colors white and light green based color.

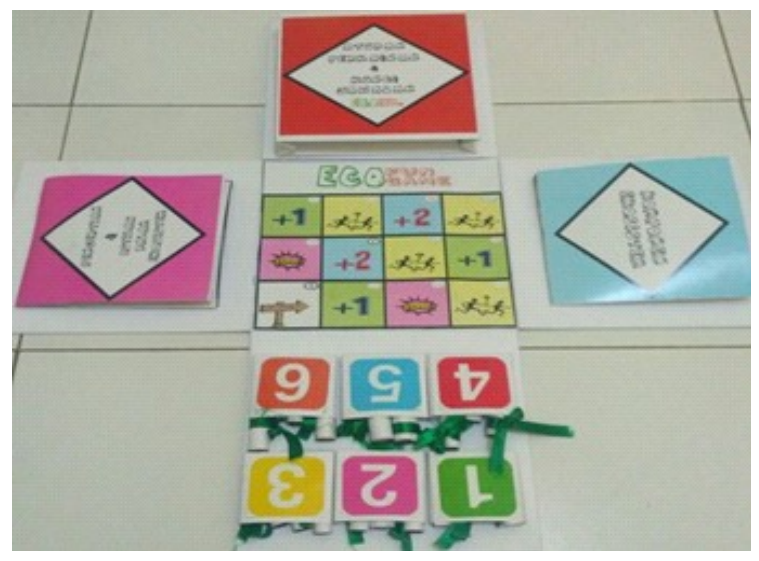

Figure 2. Display the learning media Explosion Box after opened

When the box was opened there will be four parts, there are about: the understanding of ecosystems and of the term in the ecosystem, the ecosystem components and the understanding of biotic and abiotic components, the rules of the game and the answer keys, the board of Game. In the last part, the researcher compiled a simple game that contains exercises about the material that has been presented in this Explosion Box as learning media. The game called "Eco Fun Game" with six boxes and three question in every box.

Effective learning can be achieved by real action (learning by doing) and effective learning systems for elementary school students can done by playing. This is due to the characteristics of the student's age elementary school is like to play, like on the move, likes to work in groups and likes to do or demonstrate something in person. Learning with the playing method can have an impact positive in learning activities. Therefore, the playing method can be served as an alternative to creating learning activities fun, while increasing student motivation. This matter because, the motivation of students in learning activities is very important thing, because motivation is a factor that has a lot of influence on the process and learning outcomes, so that important for teachers to carry out learning activities to be fun (Azizah, 2016).

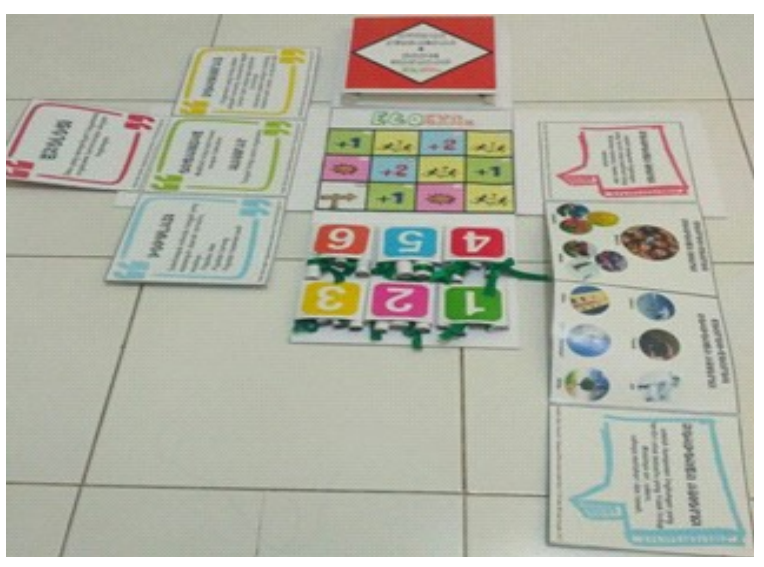

Figure 3. Display the learning media Explosion Box ready to use

After the media was ready, the next step is validation questionnaire filled by material, design and learning expert. Validation is an essential element in developing media (Aththibby, 2015). It is needed to test whether a product is suitable for use. Experts fill the questionnaire validation instructions, and answer 6 items questions and give advice to the researchers in order to be better at learning media.

The researchers then processed the data, the material expert validation obtained a percentage $93.3 \%$ within the valid category. Material expert assess the valid category on the point of appropriate as learning media to the 
ecosystem component subject matter. However, at the point of increasing motivation and learning outcomes, material expert gives points with enough valid category. Clarity of material presented to the media makes the media valid for use (Lestari, Ristanto, \& Miarsyah, 2019). This shows that the product of Explosion Box has of the appropriate material and can be used in the process of learning.

Furthermore, the design expert validation obtained a percentage $90 \%$ within the valid category. Media experts assess a valid category on the point of attractiveness on design, layout and color in the product of Explosion box. Learning media that have a display that is not confusing and easy to use by students is the main thing in improving understanding of the material (Sugandi \& Rasyid, 2019). This shows that the product of Explosion Box has of the appropriate design and can be used.

The third validation was the learning expert with obtained a percentage score of $90 \%$ within the valid category. Learning experts assess a valid category on the point of suitability as an adequate learning media. Learning media refers to a set of learning tools that will be used during the learning process that could assist the delivery of the learning materials to reach its designated goal. By that, using a proper learning media will ease the deliverance of the materials to be accepted well by the recipients (Audia, Yatri, Aslam, Mawani, \& Zulherman, 2021). This shows that the product of Explosion Box has of the appropriate learning and can be used. The advantages of Explosion Box are that it is easy to use, concrete, and can help the student to learn Ecosystem Components.

The trial of small group performed with total of 8 students randomly selected from four classes. Any class taken two students to perform the trial test in small groups. The trial of small group using the instrument the form of questionnaire which contains 6 questions. Elaboration of small group trial result can be seen in the table below.

Table 1. Elaboration of small group trial result

\begin{tabular}{clcccc}
\hline No & \multicolumn{1}{c}{ Statement item } & X & Xi & HU (\%) & Category \\
\hline 1 & $\begin{array}{l}\text { By using the Explosion Box as learning media, I } \\
\text { became more motivated to learn the material for } \\
\text { theme 5 sub-theme 1 about Ecosystem } \\
\text { Components. }\end{array}$ & 39 & 40 & 97.5 & Valid \\
\hline 2 & $\begin{array}{l}\text { By using the Explosion Box as learning media, it } \\
\text { became easier for me to understand the material for } \\
\text { theme 5 sub-theme 1 about Ecosystem Components }\end{array}$ & 38 & 40 & 95 & Valid \\
\hline 3 & $\begin{array}{l}\text { By using the Explosion Box as learning media, the } \\
\text { learning process becomes fun. }\end{array}$ & 40 & 40 & 100 & Valid \\
\hline 4 & $\begin{array}{l}\text { Explosion Box as learning media makes me more } \\
\text { active and creative. }\end{array}$ & 38 & 40 & 95 & Valid \\
\hline 5 & $\begin{array}{l}\text { I think it is easy to learn by using the Explosion } \\
\text { Box as learning media. }\end{array}$ & 38 & 40 & 95 & Valid \\
\hline 6 & $\begin{array}{l}\text { Images in the Explosion Box as learning media } \\
\text { have attractive colors. }\end{array}$ & 36 & 40 & 90 & Valid \\
\hline \multicolumn{1}{c}{ Total } & $\mathbf{2 2 9}$ & $\mathbf{2 4 0}$ & $\mathbf{9 5 . 4}$ & Valid \\
\hline
\end{tabular}


Based on the elaboration data of validation result on the table above shows the percentage $95.4 \%$. It can be noted that the total of answer score by responder which is 8 students $\left(\sum x\right)$ is 229 and the total of the maximum $\operatorname{score}\left(\sum x i\right)$ is 240 , so see the result of the validation test percentage of small group is of $95.4 \%$. This shows that the product of learning media Explosion Box has of the appropriate and can be used in the process of learning the material Components of Ecosystem on the $5^{\text {th }}$ grade elementary school. Based on that criteria can conclusion the Explosion Box product is valid as learning media.

The trial of large group performed with total of 32 students. The trial of large group using the instrument the form of questionnaire which contains 6 questions. Elaboration of large group trial result can be seen in the table below.

Table 2. Elaboration of large group trial result

\begin{tabular}{clcccc}
\hline No & \multicolumn{1}{c}{ Statement item } & $\mathbf{X}$ & $\mathbf{X i}$ & HU (\%) & Category \\
\hline 1 & $\begin{array}{l}\text { By using the Explosion Box as learning media, I } \\
\text { became more motivated to learn the material for } \\
\text { theme 5 sub-theme 1 about Ecosystem } \\
\text { Components. }\end{array}$ & 150 & 160 & 93.8 & Valid \\
\hline 2 & $\begin{array}{l}\text { By using the Explosion Box as learning media, it } \\
\text { became easier for me to understand the material for } \\
\text { theme 5 sub-theme 1 about Ecosystem Components }\end{array}$ & 151 & 160 & 94.4 & Valid \\
\hline 3 & $\begin{array}{l}\text { By using the Explosion Box as learning media, the } \\
\text { learning process becomes fun. }\end{array}$ & 155 & 160 & 96.9 & Valid \\
\hline 4 & $\begin{array}{l}\text { Explosion Box as learning media makes me more } \\
\text { active and creative. }\end{array}$ & 148 & 160 & 92.5 & Valid \\
\hline 5 & $\begin{array}{l}\text { I think it is easy to learn by using the Explosion } \\
\text { Box as learning media. }\end{array}$ & 154 & 160 & 96.3 & Valid \\
\hline 6 & $\begin{array}{l}\text { Images in the Explosion Box as learning media } \\
\text { have attractive colors. }\end{array}$ & 148 & 160 & 92.5 & Valid \\
\hline & \multicolumn{1}{c}{ Total } & $\mathbf{9 0 6}$ & $\mathbf{9 6 0}$ & $\mathbf{9 4 . 4}$ & Valid \\
\hline
\end{tabular}

Based on the elaboration data of validation result on the table above shows the percentage $94.4 \%$. It can be noted that the total of answer score by responder which is 32 students $\left(\sum x\right)$ is 906 and the total of the maximum score $\left(\sum x \mathrm{xi}\right)$ is 960 , so see the result of the validation test percentage of large group is of $94.4 \%$. This shows that the product of learning media Explosion Box has of the appropriate and can be used in the process of learning the material Components of Ecosystem on the $5^{\text {th }}$ grade elementary school. Based on that criteria can conclusion the Explosion Box product is valid as learning media. Visual media in the form of pictures (box) have the function to increase the study result beside to increase the motivation, and it was already proved in previous research (Fatimah \& Widiyatmoko, 2014) who showed the study result of the students that increase.

The results of the test by small group and large group experienced a decreased percentage results are $95.4 \%$ become $94.4 \%$. Although the result percentage large group trial decreased from the small group trial, large group test results are still valid categorized based on predetermined criteria. The existence decrease of product trial results from small group and large group are affected by different conditions. Testing the 
product to small group carried out early in the morning when all the students are in focus, moreover because in classroom there are only 8 students to the subject of the small group trial, so class atmosphere more conducive so that the use of the learning media Explosion Box is very efficient. As for the large group of trials carried out during the day, after the time of UTS (Midterm) in $11.30 \mathrm{pm}$. The student is not already visible focus to receive information and to the conditions of the class containing the 32 students can't conducive like when testing small groups of 8 students only. Based on the main function of the learning media according to Arsyad (2011) are as teaching tools, that also affect the climate, conditions, learning environments that are styled and created by teachers. So some of the things that influenced the decreased in the percentage of trial results in large groups than a small group.

Furthermore, the researchers compared the results of pre-test and post-test before and after the use of the learning media Explosion Box. The question of pre-test and post-test contains 10 multiple choice question, so the maximum score is 100 . Pre-test results show that there are 22 students who do not achieve the value of the $\mathrm{KKM}$ (Minimum Graduation Criteria) that is 80 . The results of the post-test show there are 6 students who do not achieve the value of KKM. However, from the results of pre-test and posttest showed that the presence of increased significantly after using the learning media Explosion Box.

The total recapitulation of the pre-test results noted that the average score of the pretest result is 70.3 and the average score of the post-test result is 85.9. Based on the results of the recapitulation the pre-test and post-test score can be known that there was a significant increase in student learning results before and after using the learning media Explosion Box. The results of the pre-test show the average score of 70.3 while the score results of the post-test increase to 85.9.
This results are supported by findings from previous research showing box as learning media is feasible to use in the learning process (Adi \& Fitriana, 2019). The results showed that the learning media Explosion Box for effective use in the learning process.

\section{CONCLUSIONS}

Based on the research results, it can be concluded that the product of Explosion Box as learning media was suitable and can be used in learning of Ecosystem Components. The experts validation assessment results support the product of Explosion Box as learning media to be used and implemented in learning for the 5 th grade elementary school students.

Based on the results and discussion, it is suggested that (1) it is necessary to develop a more efficient learning media in terms of time, (2) further development can be done to make Explosion Box media with simple verse, and (3) further researchers may conduct experimental research using Explosion Box as learning media in other subjects material.

\section{REFERENCES}

Adi, S., \& Fitriana, M. (2019). The developement of learning method "imagination box": an effective and efficient method to evaluate student's understanding. Jurnal Pendidikan Progresif, 9 (1), 59-66.

Apsari, A., \& Budiastuti, E. (2021). Developing an android-based learning media of making shirt collar for vocational school students. Journal of Physics: Conference Series, 1833(1).

Arifin, Z. (2011). Penelitian pendidikan metode dan paradigma baru [New educational research methods and paradigms]. Bandung: Remaja Rosdakarya.

Arsyad, A. (2011). Media pembelajaran [Learning media]. Jakarta: Raja Grafindo Persada. 
Aththibby, A. R. (2015). Pengembangan media pembelajaran fisika berbasis animasi flash topik bahasan usaha dan energi [Development of flash animation-based physics learning media for business and energy discussion topics]. Jurnal Pendidikan Fisika, 3 (2).

Audia, C., Yatri, I., Aslam, Mawani, S., \& Zulherman. (2021). Development of smart card media for elementary students. Journal of Physics: Conference Series, 1783(1).

Azizah, I. M. (2016). Efektivitas pembelajaran menggunakan permainan tradisional terhadap motivasi dan hasil belajar materi gaya di kelas IV MIN Ngronggot Nganjuk [The effectiveness of learning using traditional games on motivation and learning outcomes of style materials in IV grade MIN Ngronggot Nganjuk]. Jurnal Dinamika Penelitian, 16, No. 2.

Botty, M., \& Handoyo, A. (2018). Hubungan kreativitas dengan hasil belajar siswa kelas $V$ mata pelajaran bahasa Indonesia di MI Ma'had Islamy Palembang [The relationship between creativity and learning outcomes of $\mathrm{V}$ grade Indonesian language subjects at MI Ma'had Islamy Palembang]. JIP: Jurnal Ilmiah PGMI., Vol. 4, No.

Farhana, M., Danang, P. U., \& Rosidi, M. R. (2020). Development of learning media base on e-learning towards student learning result. Journal of Physics: Conference Series, 1539(1).

Fatimah, F., \& Widiyatmoko, A. (2014). Pengembangan science comic berbasis problem based learning sebagai media pembelajaran pada tema bunyi dan pendengaran untuk siswa SMP [Development of problem based learningbased science comics as learning media on sound and hearing themes for junior high. Jurnal Pendidikan IPA Indonesia, 3(2). Gumrowi, A. (2016). Meningkatkan hasil belajar listrik dinamik menggunakan strategi pembelajaran team assisted individualization melalui simulasi crocodile physics [Improving dynamic electricity learning outcomes using team assisted individualization learning strategies through crocodile physics simulation]. Jurnal Ilmiah Pendidikan Fisika AlBiruni, 105-111.

Hidayah, P., Untari, M. F. A., \& Wardana, M. Y. S. (2018). Pengembangan media sepeda (sistem peredaran darah) dalam pembelajaran IPA di sekolah dasar [Development of sepeda media (circulatory system) in science learning in elementary schools]. International Journal of Elementary Education, 2(4), 306.

Ichsan, I. Z., Sigit, D. V., \& Miarsyah, M. (2019). Supplementary book of green consumerism: an innovation of environmental learning based on HOTS. Tadris: Jurnal Keguruan Dan Ilmu Tarbiyah, 4 (2), 135-144.

Irfan, I., Muhiddin, M., \& Ristiana, E. (2019). Pengembangan media pembelajaran IPA berbasis powerpoint di sekolah dasar [Powerpoint-based science learning media development in elementary schools]. Indonesian Journal of Primary Education, 3(2), 16-27.

Kasim, J. J. F., Haryanto, H., \& Katili, F. (2021). Design of interactive multimedia mobile learning base on android operating system for biology subjects. IOP Conference Series: Materials Science and Engineering, 1098(3), 032016.

Kuswanto, J., Yunarti, Y., Lastri, N., Dapiokta, J., \& Adesti, A. (2021). Development 
learning media based android for english subjects. Journal of Physics: Conference Series, 1779(1).

Lestari, P., Ristanto, R. H., \& Miarsyah, M. (2019). Analysis of conceptual understanding of botany and metacognitive skill in pre-service biology teacher in Indonesia. Journal for the Education of Gifted Young Scientists, 7(2), 199-214.

Mahbub, M. Z., Kirana, T., \& Poedjiastoeti, S. (2016). Development of STAD cooperative based learning set assisted with animation media to enhanche student's learning outcome in MTS. Jurnal Pendidikan IPA Indonesia, 5 (2), 247255.

Miarsyah, M., Ristanto, R. H., Nurhayati, Mufida, S. N., Suparini, \& Zharroh, A. E. (2020). Development of adobe flash media integrated into HOTS on circulation system (AF-HOTS bicycle media). International Journal of Advanced Trends in Computer Science and Engineering, 9(1), 896-903.

Nata, I. K. W., \& Putra, D. K. N. S. (2021). Pengembangan media pembelajaran multimedia interaktif pada muatan IPA kelas V sekolah dasar [Development of interactive multimedia learning media on science content for class V elementary school]. Jurnal Ilmiah Pendidikan Dan Pengembangan, 5(2), 227-237.

Niabatul, W. (2018). Pengembangan medhia explosion box tumrap kawasisan nulis teks geguritan siswa kelas VII SMPN 26 Surabaya tahun 2017-2018 [Development of explosion box tumrap media for writing geguritan text for VII grade students of SMPN 26 Surabaya in 2017-2018]. Jurnal Baradha, Jurnal Mahasiswa UNESA.

OECD. (2015). PISA 2012 results: what students know and can do - student performance in reading, mathematics and science. Paris-France: OECD Publishing.

Paringan, O. (2018). Pengembangan media pembelajaran exploding box pop up $3 D$ pada pembelajaran tematik tema 5 subtema 1 di kelas IV sekolah dasar [Development of exploding box pop up 3 learning media on thematic learning theme 5 sub-theme 1 in grade IV elementary school]. University of Muhammadiyah Malang.

Pengelola Web Kemdikbud. (2019). Hasil PISA Indonesia 2018: Akses Makin Meluas, Saatnya Tingkatkan Kualitas. Retrieved August 19, 2021, from Biro Komunikasi dan Layanan Masyarakat Kementerian Pendidikan dan Kebudayaan website: https://www.kemdikbud.go.id/main/blog/ 2019/12/hasil-pisa-indonesia-2018akses-makin-meluas-saatnya-tingkatkankualitas

Peppler, K. A., \& Kafai., Y. B. (2007). From supergoo to scratch: exploring creative digital media production in informal learning. Learning, Media, and Technology.

RA, E. (2016). Kreasi cantik exploding box [Beautiful exploding box creations]. Jakarta: PT Gramedia Pustaka Utama.

Ristanto, R. H., Miarsyah, M., Muharomah, D. R., Astuti, T. A., Aini, S., \& Prihatin, A. . (2019). Light-board: simple media to learn photosynthesis concepts. International Journal of Advanced Trends in Computer Science and Engineering, 9 (1), 299-303.

Sugandi, M. K., \& Rasyid, A. (2019). Pengembangan multimedia adobe flash pembelajaran biologi melalui project based learning untuk meningkatkan kreativitas siswa pada konsep ekosistem [Development of adobe flash 
multimedia learning biology through project based learning to increase student creativitiy in the concept of ecosytem. Jurnal Ilmiah Pendidikan Biologi, 5(3).

Wulaningsih, R. D., Rusdi, R., \& Erawati, D. (2021). Development of android-based mobile learning modules on the immune system for madrasah aliyah negeri (MAN) 9 Jakarta. IOP Conference Series: Materials Science and Engineering, 1098(5), 052056. 